\title{
LEGAL NATURE OF TERRORIST CRIMES IN RUSSIAN LEGAL SYSTEM
}

NATURALEZA JURÍDICA DE LOS DELITOS DE TERRORISMO EN EL ORDENAMIENTO JURÍDICO RUSO

\author{
Arseniy Georgievich Babichev* \\ Elmira Robertovna Khakimova**
}

\begin{abstract}
The article examines the legal nature of terrorism from the Russian legal system point of view. The relevance of the research stems from the large scale, sophistication, and cruelty with which terrorist crimes have been committed over the recent decades. Terrorism has nowadays become a global threat, and any government, including government of the Russian Federation, must take it into consideration when formulating its domestic and foreign policy. In countering terrorist crimes, current regulations of the Criminal Code of Russian Federation take rather important part. Punishment differentiation, depending on corpus delicti and consequences, as well as correct qualification of terrorist crimes, are the most important conditions of those regulation's efficient application. This problem is in fact interdisciplinary one, which is proved by researchers from other scientific fields: not only law scientists, but also psychologists, historians, political scientists. All the listed illustrates relevance, timeliness, and expediency of researching the problems mentioned. The purpose of the study is formulating recommendations for solving the above-mentioned issues of improving the existing criminal (and other) measures and developing new viable and practically applicable criminal measures for countering terrorist crimes.
\end{abstract}

\footnotetext{
* Doctor of Law. Associate Professor. Professor of the Department of Criminal Law of the Kazan Law Institute of the Ministry of Internal Affairs of the Russian Federation (Kazan, Russia). https://orcid.org/0000-0002-8099-3449. senya-babichev@mail.ru

** Legal Sciences Ph.D. Associate Professor. Deputy Head of the Department of Criminalistics of the Ufa Law Institute of the Ministry of Internal Affairs of the Russian Federation (Ufa, Russia). https://orcid.org/0000-0001-6810-0276. elmyrakhakimova@bk.ru
} 
Keywords: Counteraction, Russian Criminal Legislation, Legal Nature, Punishment, Terrorist Crimes

Resumen: El artículo examina la naturaleza jurídica del terrorismo desde el punto de vista del ordenamiento jurídico ruso. La relevancia de la investigación se deriva de la gran escala, la sofisticación y la crueldad con que se han cometido los delitos terroristas en las últimas décadas. El terrorismo se ha convertido hoy en día en una amenaza global y cualquier gobierno, incluido el de la Federación de Rusia, debe tenerlo en cuenta al formular su política interior y exterior. En la lucha contra los delitos terroristas, las normas vigentes del Código Penal de la Federación de Rusia desempeñan un papel bastante importante. La diferenciación de las penas, en función del corpus delicti y las consecuencias, así como la correcta calificación de los delitos de terrorismo, son las condiciones más importantes para la eficaz aplicación de esas normas. De hecho, este problema es interdisciplinario, como lo demuestran investigadores de otros campos científicos: no solo juristas, sino también psicólogos, historiadores y politólogos. Lo enumerado ilustra la relevancia, oportunidad y conveniencia de investigar los problemas mencionados. El propósito de este estudio es formular recomendaciones para resolver las problemáticas descritas, para mejorar las medidas penales existentes (y otras) $y$ desarrollar nuevas medidas penales prácticas y viables para combatir los delitos terroristas.

Palabras clave: Neutralización, legislación penal rusa, naturaleza jurídica, castigo, delitos terroristas

Summary. I. Introduction. II. Literature Review. III. Materials and Methods. IV. Results. V. Discussion. VI. Conclusions. References.

\section{INTRODUCTION}

In the era of globalization, Russia seeks to improve criminal legislation in order to protect national security. This includes countering terrorist crimes by criminal law and other means. Bringing the criminal legislation of the Russian Federation in line with the principles of international law, introducing effective policies developed by other countries, norm setting, law enforcement, and preventive activities are the basis for countering terrorist crimes. At the end of the previous century, 
terrorist crimes became a global issue as a weapon of destruction and annihilation. The erasure of mental, social, religious, economic, and political boundaries between countries and people, the destruction of religion, culture, and language increase the risks of such crimes.

At the international scale, various countries adopted the 1979 International Convention Against the Taking of Hostages (United Nations, 1983), the 1997 International Convention for the Suppression of Terrorist Bombings (United Nations, 2001), and the International Convention for the Suppression of the Financing of Terrorism (United Nations, 1999). Although the number of registered crimes tends to stay at the same level, terrorist crimes are steadily increasing. This growing figure determines the relevance of preventing and countering terrorist crimes. For instance, according to official statistics, in 2018, there were 1.679 terrorist crimes, in $2019,1.806$, in 2020, 2.342, respectively, and for the period from January to August 2021, 1.607 crimes. This demonstrates that the number of terrorist crimes is increasing, while criminal law is not effective enough. There is also need for scientific substantiation of the newly adopted criminal laws at the global scale, and consideration of the particular legislative decisions to make the criminal legislation more effective in the Russian Federation.

\section{LITERATURE REVIEW}

International forums, conferences, symposia, and congresses create best conditions for the analysis of scientific discussions. For instance, at an international forum in Beijing, its Vice President, Professor He Bingsun, proposed adopting a resolution on countering terrorism. Delegates from Latin America and Europe rejected this proposal, as the official agenda of the forum did not contain this issue. Russian scientists pointed to the relevance and expediency of the discussion and adoption of this resolution, and the forum participants supported this claim. The resolution was adopted unanimously on November 30, 2015, in the People's Republic of China. Later, the heads of the delegations reported it to the governments interested in effectively countering terrorism, including Russian Federation.

At present moment, there is a need for a comprehensive comparative Russian legal system analysis that would combine legal and other resources and contribute to the development of a mechanism for countering terrorist crimes. In Russian legal science, Yu. I. Avdeev (2006), Yu. M. Antonyan (1998), A. S. Batyshev (2005), Yu. S. Gorbunov (2008), V. V. Luneev (2006), and S. I. Grachev (2010) formed the basic approach to the study of terrorism. P. V. Agapova (2014), A. G. Bezverkhova (2013), and S. V. 
Bespalova (2012) examined some issues of legal regulation of countering terrorism and increasing its efficiency. E. G. Lyakhov (1987), N. P. Medvedev (2015), E. G. Ponomareva and A. Dimitrovskaya (2018), E. V. Kunts, and M. F. Kostyuk (2021) studied international terrorism from the point of view of Russian legal science. The interdisciplinary aspects of this problem were explored by V. Yu. Golubovsky, M. F. Kostyuk, and E. V. Kunts (2020). We would also like to mention such international researchers as Ch. M. Bassiouni (2001), B. Saul (2006), H. Hegemann (2014), J. Jacobs, and K. Potter (1998).

\section{MATERIALS AND METHODS}

We used a set of scientific methods to identify the legal nature of terrorist crimes in Russian legal system as the methodological basis of the research. In this study, we applied scientific research methods (system analysis, methods resulting in justified disputes between opposing positions, and comparative methods), as well as legal research methods (interpretation of legal norms). Within the framework of the generally accepted research methodology, the systematic approach enabled us to comprehensively consider the legal features of terrorist crimes. The method of discussion (consideration of various positions) allowed us to obtain the body of knowledge. This method studies a material or theoretical phenomenon in the context of its development and evolution and reflects the specific historical conditions of time and place. In addition to this, we used comparative methods to analyze trends, stages, and outcomes of these crimes in Russia. Methods of interpretation of legal norms helped us to understand the essence and content of the considered norms and to outline the will of the legislator.

\section{RESULTS}

The security plan of the Russian Federation is one of the most important measures for ensuring the security of the state and society. It implies improving legal regulation for countering terrorist and extremist activities. The Russian Constitution does not directly regulate counterterrorist activities, but it establishes the constitutional and legal foundations of such regulation. Here we would like to mention the provisions that stipulate freedoms and rights of citizens, powers of state authorities, and foundations of the state structure. At the same time, research publications claim that in the future, it will be necessary to expand the 
provisions of the Constitution of the Russian Federation that determine the foundations of human, social, and state security and aim to prevent any threats to it, including terrorist crimes.

Other legal aspects of combating terrorism in the Russian Federation are properly developed. This is why the prevention, suppression, investigation, and solution of terrorist crimes are quite successful, and those committing such crimes are adequately punished. Most of the provisions currently applied are based on the experience and take into account the corrected errors, inconsistencies, and gaps. However, at present, there are some obstacles to the legal regulation of anti-terrorist activities. Eliminating them will significantly increase the effectiveness of the fight against terrorism.

Researchers often use such terms as "terrorist crime", "terrorist offence", and "terrorist act". Some scientists attribute crimes with terrorist goals (Articles 209, 210, and 211 of the Criminal Code of the Russian Federation) to the crimes of terrorist nature (Articles 2051, 206, 207, 277, 208, and 360 of the Criminal Code of the Russian Federation). Other authors claim that apart from the articles directly establishing punishment for various kinds of terrorist activities, there are about 40 articles with dispositions that do not implicitly outline terrorist activities, but their implementation in a certain way contributes to terrorism. These crimes undermine public and state security and the constitutional order, threaten the peace and security of humankind, negatively affect the administration and military service, endanger traffic and the use of vehicles, cause harm to the environment, and lead to cybercrime.

Each of the opinions considered above is reasonable. In this research, to generalize the existing views and since there are crimes with a terrorist purpose, crimes of terrorist nature, and those connected with terrorist activities, we will refer to this group as "terrorist crimes".

The current laws of the Russian Federation do not provide for the term "a terrorist crime" and lists of acts that belong to this category. The concept of "a crime of terrorist nature" is used in paragraph $b$ of Article 11 of the Concept on Combating Terrorism (President of the Russian Federation, 2009), but the document does not give the definition or the list of crimes for this group. In this case, experts believe that society and law enforcement agencies cannot consider such crimes as terrorist and properly respond to them. The Criminal Code of the Russian Federation (1996) specifies seven corpus delicti, the name or disposition of which is directly linked with terrorism (Articles 205-2056 and 361 containing a footnote to the list of terrorist acts).

Having analyzed the sources, we established that the number of terrorist crimes ranges from 9 to 21 in the proposed list that can be found in the 
regulatory legal acts of the Russian Federation. Obviously, the legislator has an ambiguous approach to the list of crimes within this group, which disorients the executor of law. Therefore, the list of terrorist acts should be stipulated in legislation; otherwise, it is quite difficult to define terrorist threats.

However, recently, Russian legislation on countering terrorism has been changing, which allows adjusting the list of terrorist acts, footnotes to which are contained in regulatory acts.

\section{DisCUSSION}

The concepts of "terrorism", "terror", and "terrorist act" have a long history in the Russian language. At the same time, the analysis of relevant research papers shows that almost all of them tend to focus on the word "terror" when defining terrorism. However, the meaning of the word "terror" in English and French does not completely coincide with the Russian one.

In the Russian language, "terror" is a violent action, whereas in English and French there are two meanings equally used: the first one is fear, horror, and anxiety, and the second, actions that arouse similar feelings. Here we would like to note that French and English publications on the issue often use such concepts as "subjective" and "objective" terrorism. The former denotes the feeling of fear, anxiety, and horror one person or several people have, while the second refers to the actions that cause these feelings. The established concept of "terrorism", which is a derivative from the second ("objective"), meaning of the word "terror", in its most general form means the intimidation of an individual or a group of people with violence. This act of violence aims to frighten more people than directly suffered from the attack.

Over four decades of the $20^{\text {th }}$ century, there was an assumption that support for terrorism is any deliberate activity that implies providing intellectual (training, instruction, and giving information) and (or) material (financing, recruiting, and supplying weapons) assistance for the purpose of unhindered and systematic commission of terrorist crimes. In other words, international anti-terrorism legislation interprets the concept "support for terrorism" in a very broad way: not only as immediate complicity in the perpetration of certain offenses of terrorist nature, but as indirect support for various types of terrorism.

Russian criminal legislation on the responsibility for supporting terrorist activities evolved in two directions: in its General Part (the concepts of unfinished crime and complicity) and in its Special Part (specific elements of state crimes and crimes against public safety). We can single out three stages in this development: 
(i) Emergence and formation of general legal foundations for the criminalization of support for terrorist activity in the pre-revolutionary criminal legislation of Russia (the $10^{\text {th }}$ - early $20^{\text {th }}$ century).

(ii) Creation of immediate prerequisites for the criminalization of the assistance to terrorist activity in the codified criminal legislation of Russia during the Soviet and post-Soviet periods (1922-2002).

(iii) Criminalization of the support for terrorist activity, when in 1996 the Special Part of the Criminal Code of the Russian Federation stipulated it as a specific element of crime, and next its content is altered and extended (2002-to the present moment).

When classifying a particular crime as a "crime of terrorist nature", Russian law enforcers working in the antiterrorist sphere rely on interdepartmental normative legal acts that aim to ensure a unified approach and comprehensive presentation in Russian federal statistical monitoring. On March 10, 2006, the Law "On Countering Terrorism" (Russian Federation, 2006) came into force, and Article 207 of the Criminal Code of the Russian Federation (1996) was removed from the list of terrorist criminal acts. This is fair and reasonable, but some researchers disagree with this decision. The object of the offence of knowingly false notification of a terrorist act is not public safety and state security, but public order and the stable functioning of various institutions. The commission of this crime is often associated with hooliganism and does not pursue terrorist goals. If there are terrorist goals in a certain act, one must consider it a threat to commit a terrorist act.

The purpose of a crime is an additional criterion of the corpus delicti, which allows distinguishing between intentional and unintentional acts. There is a certain mental model of the final result a person who has committed a criminal act is trying to achieve. The purpose is considered as a mandatory criterion when it is directly indicated in the disposition of an article of the Special Part of the Criminal Code of the Russian Federation, or when it is necessary due to the legal nature of a certain element of crime.

Purposes and motives are the foundations, the psychological basis for the arising responsibility. The purpose and motive are a prerequisite for criminal punishment for an act that is not criminal, if the law does not state the presence of them. It is the criterion used to determine this or that corpus delicti-a qualifying criterion, that is, an aggravating factor that increases punishment and responsibility.

Terrorist acts have an incredibly complex social and political basis: terrorism When assessing an act as such a crime, one should primarily rely on the presence of a certain terrorist purpose, which one should understand as intended and planned result of this terrorist activity. 
At present, there is no legal definition of terrorist purposes, and only particular articles of the Criminal Code of the Russian Federation mention the special purpose. Articles 2053 and 2054 of the Criminal Code of the Russian Federation stipulate the purposes of undergoing the training and the formation of a terrorist association for the commission of terrorist activities or the implementation of certain terrorist criminal acts. The crime provided for in Article 206 of the Criminal Code of the Russian Federation is closely connected to Article 205 of the Criminal Code of the Russian Federation. Previously, hostage taking was a separate form of terrorist activity; however, over time, it acquired the status of an independent crime under the influence of international law. Hostage taking may be considered a terrorist act when it is carried out in a way that is dangerous to society, and its purpose is to influence the decision-making by the authorities for the benefit of the perpetrators.

Hostage taking has a purpose different from that of a terrorist act: in addition to influencing the state, it aims to compel some state body or person to take one or another action or, on the contrary, not to commit it.

Legal experts have different opinions on whether Article 281"Sabotage" - of the Criminal Code of the Russian Federation belongs to terrorist acts. Some mention the similarity of the disposition of this article and the disposition of Article 205 of the Criminal Code of the Russian Federation. However, there is a significant difference: the purpose of the crime committed, which, in case of sabotage, aims to destabilize the economy and the defense capability of the Russian Federation. In contrast, the purpose of a terrorist act is to undermine the activities of state bodies or pressure the authorities. Depending on the purpose, the same actions associated with explosions or arson will be classified under Article 205 or 281 of the Criminal Code of the Russian Federation. The same approach should be used when attributing Articles 277 and 295 of the Criminal Code of the Russian Federation to the category of terrorist crimes. However, similar to Article 206 of the Criminal Code of the Russian Federation, these acts may have an ultimate goal that is connected with terrorism. In other words, crimes may be ordinary or terrorist by nature, and one should differentiate them according to the final purpose that they pursue.

Therefore, having analyzed the existing gaps, we revealed that it is necessary to formulate and enshrine at the statutory level the term "terrorist crime" in the Law "On Countering Terrorism".

When drafting the wording, at first, one should remember that there is a specific terrorist purpose, similar to the purposes provided for in Articles 205 and 361 of the Criminal Code of the Russian Federation and the Federal Law of the Russian Federation "On Countering Terrorism" (2006). These 
measures allow establishing greater responsibility for the commission of acts provided for by special norms referring to a terrorist purpose. It also makes it impossible to classify ordinary crimes as terrorism, excludes the practice of "double" account of actions as crimes of terrorist and extremist nature, as well as provides objective statistics.

Considering the above, we believe that the "terrorist crime" should be defined in the Federal Law of the Russian Federation "On Countering Terrorism" as a guilty socially dangerous act aimed at achieving terrorist goals. In other words, it is a negative impact on the activities and decisions of authorities or international organizations, peaceful coexistence of states and peoples, or directed against the interests of the state (group of states). The Law (2006) should establish a list of terrorist crimes, which should include the crimes provided for in Articles 205, 2051, 2052, 2053, 2054, 2055, 2056, 211 (part 4), and 361. Also, they are considered in Articles 206, $208,220,221,277,278,279,281,295,318,360$, and other articles of the Criminal Code of the Russian Federation, if they are committed for terrorist purposes or are connected with terrorism.

\section{ConCLUSIONS}

1. Summing up all of the above, we would like to note that the current Russian criminal legislation in the field of countering terrorist crimes is actively developing, as evidenced by the rulemaking of recent years. At the same time, the Federal Law of the Russian Federation "On Countering Terrorism" (2006) should define "terrorist crime" as follows: it is a guilty socially dangerous act aimed at achieving terrorist goals, that is, negatively affecting the activities and decisions of government bodies or international organizations, peaceful coexistence of states and peoples, or directed against the interests of a state (group of states).

2. Terrorist crimes always aim at the main target: public safety. However, not all researchers support this point of view: as the analysis of international publications and legislation has shown, terrorist crimes are often recognized as crimes that encroach on the state (institutions of state power), as well as crimes that infringe on the peace and security of all humankind. As the conducted study demonstrated, there are many problems in the field of qualification and differentiation of terrorist crimes. As for the objective side of terrorist crimes, they may vary within almost the entire spectrum of the actus reus (depending on the specific element of the crime), which cannot be examined in a single study. 
3. By establishing a low age of criminal responsibility for crimes under Articles 205, 206, and 361 of the Criminal Code of the Russian Federation, the legislator reflected the great public danger of these crimes and the large share of them committed by adolescents. This is due to the specific development of adolescents and their ability to understand the social significance of such acts and the punishment for committing such crimes. The age of discretion under Article 205 of the Criminal Code of the Russian Federation was reduced due to the large number of adolescents used in terrorist acts and due to their age when they easily fall under the influence of adults and commit terrorist acts under their supervision. However, we would like to note that when adolescents commit such crimes, they do not act independently, do not initiate these crimes: in the overwhelming majority of cases, they themselves are victims of the negative influence of adult criminals, who force teenagers into committing terrorist crimes using various psychological tricks and affecting the unformed psyche of an adolescent. 


\section{REFERENCES}

Agapov, P. V. (2014). The Latest Anti-Terrorist Legislation: Problems of SocioCriminological Conditionality. Society and Law, 1 (47), 73-77.

Antonyan, Y. M. (1998). Terrorism: Criminological and Criminal Law Research. ShieldM.

Astanin, V. V. (2000). Corruption and Fighting Against It. Russian Criminological Association.

Avdeev, Y. I. (2006). Theoretical Foundations and Historical Prerequisites for the Creation of a Nationwide System of Fight against (Combating) Terrorism in Russia. Moscow.

Bassiouni, C. M. (2001). International Terrorism: Multilateral Conventions, 1937-2001. Transnational Publishers.

Batyshev, A. S. (2005). Russian Society and Terrorism: Comprehension of the Truth. Egves.

Bespalov, S. V. (2012). Transnational Islamist Terrorism as a Global Problem. PolitBook, $3,73-82$.

Bezverkhov, A. G. (2013). "Terrorism" and "Terrorist Act": Criminological and Legal Analysis. Bulletin of the Samara Humanitarian Academy. Series: Law, 1, 5366.

Chernyadieva, N. A. (2016). International Terrorism. Origin, Evolution, Topical Issues of Legal Opposition. Prospekt.

Gorbunov, Y. S. (2008). Terrorism and Legal Regulation of Combating It. Molodaya Gvardiya.

Grachev, S. I. (2010). Terrorism and Counter-Terrorism Activities: Theoretical Issues. NNSU of N. I. Lobachevsky.

Hegemann, H. (2014). International Counterterrorism Bureaucracies in the United Nations and the European Union. Nomos.

Jacobs, J., \& Potter, K. (1998). Hate Crimes. Criminal Law and Identity Politics. Oxford University Press.

Kunts, E. V., \& Golubovskiy, V. Y. (2016). The Legal Nature of Ethnic and Religious Conflicts. Indian Journal of Science and Technology, 8, 1-7.

Kunts, E. V., \& Kostyuk, M. F. (2021). Terrorismo contemporaneo: problemas de conceito e prevencao. Laplage em Revista, 7 (3), 232-238. Doi: https://doi.org/10.24115/S2446-62202021731292p.232-238

Luneev, V., Kudryavtsev, V. N., \& Petrishchev, V. E. (2006). Terrorism and Organized Crime in the Globalized World. Science.

Luneev, V. V. (1999). Crime of the $20^{\text {th }}$ Century. Global Criminological Analysis. NORMA Publishing House. 
Lyakhov, E. G. (1987). The Politics of Terrorism is the Politics of Violence and Aggression. Mezhdunarodnye Otnosheniya.

Medvedev, N. P. (2015). CIS: Problems of Post-Soviet Reintegration. Eurasian Union: Issues of International Relations, 1-2 (10-11), 148-155.

Ponomareva, E. G., \& Dimitrovskaya, A. (2018). Balkan Knot of International Terrorism. Observer, 5 (340), 37-51.

President of the Russian Federation (2009). Concept on Combating Terrorism. Moscow.

Russian Federation (1996). The Criminal Code of the Russian Federation [amended on 1VII-2021]. State Duma and Federation Council.

Russian Federation (2006). Federal Law 35-FZ “On Countering Terrorism”. State Duma and Federation Council.

Saul, B. (2006). Defining Terrorism in International Law. Oxford University Press.

United Nations (1983). International Convention against the Taking of Hostages. United Nations-Treaty Series, 1316, 205-211.

United Nations (1999). International Convention for the Suppression of the Financing of Terrorism.

United Nations (2001). International Convention for the Suppression of Terrorist Bombings. Penal Matters, XVIII (9).

United Nations (2006). Global Counter-Terrorism Strategy of the United Nations (Along with the Action Plan): Resolution No. 60/288 of the UN General Assembly. 